\title{
IQGAP2 wt Allele
}

National Cancer Institute

\section{Source}

National Cancer Institute. IQGAP2 wt Allele. NCI Thesaurus. Code C119674.

Human IQGAP2 wild-type allele is located in the vicinity of $5 q 13.3$ and is approximately $305 \mathrm{~kb}$ in length. This allele, which encodes Ras GT Pase-activating-like protein IQGAP2, is involved in the modulation of the activity of small GT Pases. 